\title{
CONF- $4410198-1$
}

USE OF HEALTH EFFECT RISK ESTIMATES AND

UNCERTAINTY IN FORMAL REGULATORY PROCEEDINGS:

A CASE STUDY INVOLVING AIMOSPHERIC PARTICULATES

L. J. Habegger

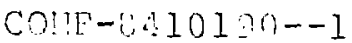

Argonne National Laboratory

$D .0 .5 \quad 00.2727$

9700 s. Cass Avenue

Argonne, Illinots 60439

and

A. H. Ozka ynak

Harvari University

79 JFK Street

Cambridge, Massachusetts 02138

\section{ABSTRACT}

Coal combustion particulates are released to the atmosphere by power plants supplylng electrical energy to the nuclear fuel cycle. This paper presents estimates of the public health risks associated with the release of these particulates at a rate associated with the annual nuclear fuel production requlrements for a nuclear power plant. Utilization of these risk assessments as a new component in the formal evaluation of total risks from nuclear power plants is discussed.

KEY WORDS: Particulate health effects; nuclear fuel cycle; risk assessment; Isik management; regulatory pruceedings.

\section{DISCLAIMER}

This report was prepared as an account of work sponsored by an agency of the United States Government. Neither the United States Government nor any agency thereof, nor any of their employees, makes any wirranty, express or implied, or assumes any legal liability or responsibility for the accuracy, completeness, or usefulness of any information, apparatus, product, or process disclosed, or represents that its use would not infring: privately owned rights. Reference herein to any specific commercial product, process, or service by trade namc trademark, manufacturer, or otherwise does not necessarily constitute or imply its endorsement, recommendation, or favorin; by the United States Government or any agency thereof. The views and opinions of authors expressed herein do not necessarily state or refect those of the United States Government or any agency thereof.
MSTER

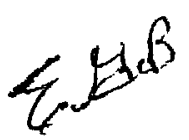

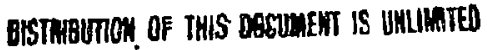




\section{INTRODUCTION}

It has been eatimated that 323 thousand megawart-hours (Mwhr) of electrlcity are required to manufacture and process the average annual fuel requirements of a 1000 megawat nuclear power plant.1,2 Because of the iagnitude of this requirement, the environmental impacts of the air emissions from facilities generating this electricity have been included as a consideration in the overall 1mpact of the operation of nuclear power plants. The results of these considerations have, however, previously in general been that these alr emissior impacts are not significant on the basis of thelr small contribution (less than $0.02 \%$ ) relative to the total of other national atmospheric emissions. ${ }^{3}$ The impact of the atmospheric amissions on the ambient air quality would not be expected to cause violations of Clean Atr Act requ1rements.

In the operating license hearings for the Harris nuclear power plant, the Atowic Safety and Licensing Board (ASLB) ruled in favor of the argument that further analysis is necessary to determine the environmental impacts of effluents released in the uranlum fuel cycle. Specifically, further testimony was considered necessary to quantitatively address the iealth effects of the coal combustion particulates released during the generation of electricity utilized in the urantin fuel cycle. ${ }^{4}$ The purpose of this paper is to (1) describe the sclentific basis and results of a health effects risk assessment performed in response to the ASLB directives, 5 and to discuss some of the constrainis or factors that must be considered in cases such as this in which a risk assessment that irvolves uncertainty provides direct input to the formal risk management (regulatory) procsss.

The foremost constraint 1mposed on the analysis was that the particulate emissions to the atmoiphere are 1154 miric tons (MT) per year as 11sted in 
Table S-3, "Table of Uranium Fuel Cycle Environmental Data," given in I'ftle 10. Part 51 of the Code of Pederal Regulations (CFR). This listed emission rate is based on out-dated information, and, as is discussed later, actual emissions are currently considerably lower. Also, the analysis was constrained by the ASLB hearing process to consider only primary particulate emlssions, even though Table s-3 also listed emissions of sulfur orides and other pollutants.

\section{AIR QUALITY AND EXPOSURE ANALYSIS}

of the 323 thousand megawat-hours (Mwhr) of electricity given in Table S-3 as the total annual requirement for the fuel cycle for the model LWR plant, approximately $96 \%$, or $310,00 \mathrm{Mwhr}$, 1s required to perform the uranium isotope enrichment step of the fuel cycle. ${ }^{2}$ At present, there are three facilities that could provide uranium enrichment for the fuel for the Harris plant. These are the gaseous diffusion plants (GDPs) located near Portsmouth, Ohlo; Paducah, Kentucky; and Oak Ridge, Tennessee. Power for the GDPs is drawn from utility grids, and because of the intercannections it is not consistent with actual conditions to completely associate increased electrical generation, and thus increased particulate emissions, with any specific Individual power plant. Allocating the generation to the mix of plants in the utility grid, 1ncluding hydro, oll, gas, and nuclear would, however, be Inconsistent with the constraints that the particulate emissions are fixed at a level of $1154 \mathrm{MT} / \mathrm{gr}$ and associated with coal-fired generation.

The approach used in this anel ysis was to compare the results of three separate analyses that each sssume the total electrical generation, and thus the total $1154 \mathrm{MT} / \mathrm{gr}$ particulate emissions, occurs alternatively at one of three coal-fired power plants that were constructed primar1ly to provide power 
to the GDPs. One of these is the Joppa piant In Massac County, IL, which has 735 of 1 ts 1100 kw capacity "dedicated" to the Paducah GDP. The additional twc plants considered were the Kgger Creek and Clitty Creek plants with capacities of 1086 and $1304 \mathrm{Mw}$, respectively. ${ }^{6}$ The Kyger plant In Gallia Count $y, \mathrm{OH}$, and the Clifty Creek plant in Jefferson County, IN, are dedicated to the Portsmouth GDP, whlch had a 1980 total power requirement of 2260 Mw. In the remainder of this paper, oniy the analysis and results related to the Kyger Creek plant are presented; similar results were obtained for the other two plants.

Ar Initial aspect of the risk assessment for this plant was the further characterization of the emission source. The value of stack parameters used In the estimation of plume rise for the Kyger Creek plant ${ }^{6}$ were: stack height, $305 \mathrm{~m}$; Inside stack diameter, $8.94 \mathrm{~m}$; exit velocity, $33.5 \mathrm{~m} / \mathrm{s}$; exit temperature, $149^{\circ} \mathrm{C}$.

The emission rate assoclated wth the electrical generation for the uranium fuel cycle was assumed to be $1154 \mathrm{MT} / \mathrm{yr}$ as findicated in Table s-3. Table s-3, however, does not provide data on particulate size distribution, which is critical in the estimation of related health risks. Using avallable data for fulverized-coal fired bollers, ${ }^{7}$ an estimated $7900 \mathrm{MT}$ of fly ast. is emitted without controls, and approximately $10 \%$, or 790 MT of the particles have diameters $2.5 \mathrm{mfcrons}(\mu \mathrm{m})$ or less; $35 \%$, or $2760 \mathrm{MT}$ of the particles have diameter in the range of 2.5 to $15 \mathrm{fm}$; and the remaining $4350 \mathrm{MT}$ of particles have diameters greater than $15 \mu \mathrm{m}$.

To obtain the Table S-3 particulate emission level of $1154 \mathrm{MT} / \mathrm{yr}$, It must be assumed that only $85.4 \%$ of the $7900 \mathrm{MT} / \mathrm{yr}$ of ash carried in the flue gas is removed. This modest level of emission control can be achieved by various types of control devices. However, the relative rate of removal of different 
particle sizes is dependent on details of control device design, which are not specified In Table s-3 or cited references. Because of the unknowns in the contral device design used as a basis for Table S-3, a conservative approach was used in the analysis for this testimony Id $_{\text {which }}$ it was assumed that all of the least harmful particulates greater than $15 \mathrm{fm}^{\mathrm{m}}$ are collected, none of the most harmful particulates less than 2.5 ful are collected, and the level of control on the midsize 2.5 to $15 \mu$ particles is adjusted to give total emission rate of $1154 \mathrm{MT} / \mathrm{yr}$. The result of this approach gives $790 \mathrm{MT} / \mathrm{yr}$ emissions of less than $2.5 \mu$ and $364 \mathrm{MT} / \mathrm{yr}$ of emlscions in the 2.5 to $15 \mu \mathrm{m}$ range.

The above approach to characterizing the particulate emfssions was designed to given an overall conservative result that overestimates health effects of the coal particulates. The actual Joppa, Clifty Creek, and Kyger Creek power plants emit particulates at a considerably lower rate than that given in Table 5-3. For example, the Kyger Creek plant has an ESP with greater than $99.8 \%$ test efflclency and $99.4 \%$ design efficiency. This range of efficlencies gives estimated total particulate emissions of 16 to 114 MT assoclated with 323 thousand Mwhr generation. With the high removal efficiency of ESPs, a significant fraction of particles with diameters less than $2.5 f^{m}$ is also removed. For example, using the calculation procedures given in Reference 7, it is estimated that approximately 70\% of the 0-2.5 $\mu \mathrm{m}$ particle size range 18 removed with an ESP that has an overall removal efficlency of $96.5 \%$ for all particulates.

The afr pollutant dispersion modeling conducted in the analysis was based on hourly data for wind speed and direction, temperature, and helght of the surface mixing layer. For the Kyger Creek plant, this input data was obtained from surface and upper alr jata collected at Huntington, w. The U.S. 
Environmental Protection Agency (EPA) recommends that five consecutive years of data be used to obtain representative conditions and 1971-1975 data was used for the Kyger Creek site. A small difference in estimated concentration among the flve years of analysis, as described below, Indicates that selection of year of meteorological record does not change the overall conclustons of this testimony.

Topography can affect ground-level concentrations and was an input to the alr pollutant dispersion model. At each location where the atmospheric particulate concentration was estimated, the elevation relative to the power plant was obtained from area maps compiled by the U.S. Geological Survey.

Amblent particulate concentration increments based on this data was estimated using the Industrial Source Complex (ISC) computer model. 8 This is a standard mode: recommended by the U.S. EPA for use in air dispersion analysis for regulatory purposes. The ISC model has the capability to simulate particle removal by deposition, which results in lower concentrations, especially at distant receptor points. However, this feature was not ut1lized, which adds further to the conseriatism of the analysis.

The particulate concentration and population exposure analysis covered a circular area of 50 miles radius with the power plant emission source at the center. The circular areas were divided into 360 grid cells with boundaries formed by radials at $10^{\circ}$ Increments and 10 concentric rings.

The accuracy of the ISC model applied to a single source is dependent on the 8pplication. The annual average concentration is used to quantify health risks and it 18 for such long-term averages that the better model accuracy usualig results. As an example, a recent comparison between ISC predictions and monitored annual averages for particulates was performed in the vicinity of an industrial source in Minnesota.9 After the computed background from other sources was subtracted from the observed monttoring data, the ISC- 
predicted annual averages at 6 locations ranged from an underprediction of $17 \%$ to an overprediction of $6 \%$. For shorter term averages, such as the 24-hour maximums, a lesser predictive accuracy of within a factor of approximately 3 to 5 is usual. 10

The averaging times that correspond to the National Ambient Air Quality Standards (NAAQS) for particulates are annual averages and maximum 24-hour average concentrations. For Kyger Creek, the maximum annual averages using the avallable 1971-1975 meteorological data were $0.010,0.009,0.013,0.011$ and $01013 \mu \mathrm{gg} / \mathrm{m}^{3}$, respectivel $\mathrm{y}$, and $0.60,0.33,0.51,0.47$, and $0.71 \mu \mathrm{gg} / \mathrm{m}^{3}$ for the 24-hour maximum. Assuming the particulates are conserved in the atmosphere (no deposition or transformation) the particle size distribution in the atmosphere is the same as for the emfssion source, $1 . e ., 68 \%$ less than $2.5 \mu m$ in diameter and $32 \%$ in the 2.5 to $15 \mu \mathrm{m}$ diameter range.

For comparison the NAAQS primary standards (ilizended to protect public health) for particulates is $75 \mu \mathrm{g} / \mathrm{m}^{3}$ for annual averages and $260 \mu \mathrm{g} / \mathrm{m}^{3}$ for 24hour maximums. Based on the estimates obtained in this analysis, the concentrations associated with the lable 5-3 level of emissions would contribute only a very Insignificant increment relative to the NAAQS.

An additional base for eviluating the significance of these concentrations is in comparison to increments allowable in "pristine" areas designated as Class I areas under the regulations for prevention of signfficant afr quality deterioration. 11 In class I areas the maximum increment in particulate concentrations allowable from new development is $5 \mu \mathrm{g} / \mathrm{m}^{3}$ for annual average and $10 \mu \mathrm{g} / \mathrm{m}^{3}$ for 24 -hour maxfmum. Although there are no designated Class I areas within 100 miles of any of these power plants considered, the increment in particulate concentration from the Table s-3 level of emisstons would not be cause for concern relative to these stringent standards even if they did apply. 
No estimates were made of Incremental particulate concentrat in beyond the 50-mile radius surrounding the power plants. Th1s was not done for reasons simllar to those expressed in EPA statements related to implementation of regulations for pievention of significant deterioration (PSD)" : "the [EPA] Administrator intends to limit generally the application of a1r quality wodels to a downwind distance of no more than 50 kflometers. This is because dispersion parameters commonly in use are based on experiments relatively close to sources, and extending these parameters to long downwind distances results in great uncertainty as to the accuracy of the model estimates at such distances. Also, since the alr quality impact of many sources falls of rapidly to inslgnificant levels, EPA does not intend to analyze the 1mpact of a source beyond the point where the concentrations from the source fall below certain levels $\left[1 \mu \mathrm{g} / \mathrm{m}^{3}\right.$ for annual average particulates]." From the computer calculations, for the $1154 \mathrm{MT} / \mathrm{yr}$ emlssions, nowhere within the vicinity of the three power plants does the estlmated annual average incremental concentration approach the $1 \mu \mathrm{g} / \mathrm{m}^{3}$ annual average recommended cut-off for PSD modeling and In the outer 40-50 mile (65-80 kllometer) band the mean of the annual average incremental concentration is only $0.003 \mu \mathrm{g} / \mathrm{m}^{3}$ for the $k$ yger Creek plant. Thus, based on EPA guidelines for PSD, estimation beyond 50 miles ( 80 kilometers) is not recommended.

The basic appruach for computing human exposure resulting from the incremental amblent particulate concentrations was to estimate the population in each of the 360 receptor grid cells surrounding each of the three power plants. The estimated population in each cell is assumed to ve exposed to the particulate concentration increment estimated for the cell midpoint.

Esifmates of the population in each grid cell are derived from data collected by the U.S. Bureau of Census for block groups (in urban areas) and 
enumeration districts (in rural areas). The population for each of the geographic units whose centrold is located within a grid cell 18 assumed to be totally located within that cell. The varlous other census data, e.g., population by age, sex, occupation, education, is also avallable. For this analysis the 1980 census data was used.

W1thin a 50-mile radius of the Kyger Creek plant the total estimated 1980 populations was 870,000 . The total computed population exposure (sum over all grid cells of population times concentration) using the annual average concentrations was 2174 for Kyger Creek (mean of 1971-1975). The total computed population exposure using the maximum 24-hr concentration in each grid cell was 47,200 for Kyger Creek (mean of 1971-1975). The population-weighted average (sum of exposures divided by population) over all grid cells was $0.0025 \mu \mathrm{g} / \mathrm{m}^{3}$ for the 1ncremental annual average particulate concentration and $0.054 \mu \mathrm{g} / \mathrm{m}^{3}$ for the maximum incremental 24-hour concentration (mean of 19711975). The population-weighted averages can be interpreted as the concentration to which the average individual in the area of analysis is exposed.

\section{ASSESSMENT OF POPULATION HEALTH EFFECTS}

In this section is quantified the likely extent of population healch risks within the 50-mile radius of the power plants resulting from the primary particle emissions of $1154 \mathrm{MT} / \mathrm{yr}$. Various morbidity and mortality health outcomes were considered, Including both, chronic and acute* effects. Acute resplratory disease Incidents and hospital respiratory disease emergency

* Acute (respiratory) morbidity indicates short-term iliness such as pneumonia, Influenza and common coughs, while chronic (respiratory) morbidity 1ndicates persistent, long-term 1llness such as chronic bronch1tis, bronchial asthma or other obstructive lung disease. 
admissions were among the morbldity health outcome variables st-idied. For chronic morbldity, chrontc resplratory disease prevalence was considered.

For acute mortality effects of particle pollution, dally long-term (timeserles) mortality risk coefficients were used. For chronlc mortality effects, cross-sectional mortality coefficiento relating annual mortality and annual average pollution in a large number of Standard Metropolitan Statistical Areas (SMSAs) in the U.S. were employed. Finally, toxicologic evidence regarding exposures to particles at or near the projected pollution levels were reviewed.

Basically there were two avallable approaches to characterize the health 1mpacts assoclated with the emitted particles. One was to rely heavily on EPA's recent criteria document on particulate matter and sulfur oxides, 12 and the second was to conduct or rely on a risk analytic approach orlented toward providing numerical exposure-response information.

The second approach was selected primarily because neither the EPA's crlterla document nor the EPA Offlce of Air Quality Planning and standards (OAQPS) staff review of the criteria document 3 provide quantitative exposure/response information for concentrations as low as those projected for this study. The EPA documents vere, however, used to gulde the selection of toxicologic and epldemlologic data bases that could be used to derive exposure-response coefficients or relationships.

If the EPA criteria document had been used solely we could only have concluded, and only qualitatively, that the projected health effects assoclated with the particulate emfssions would most $11 \mathrm{kel} y$ be negligible and undetectable. To fllustrate, Table 1 summarlzes the levels of baseline and (Table 1 about here) 
incremental particle pollution impacts in the geographic area studied. Since most of the projected concentration impacts are extremely small, the changes In the amblent particulate levels burrounding the three plants are negligible, and the baseline or background plus incremental concentration 18 on the average, are less than $70 \mu \mathrm{\mu g}^{3}$ (annual average) for Total Suspended Particulates (TSP) and less than $25 \mu \mathrm{g} / \mathrm{m}^{3}$ for Fine Particulates $(<2.5 \mu \mathrm{m})$. A recent Federal Register notice by the EPA ${ }^{15}$ proposes an annual $\mathrm{PM}_{10}$ particle (those particles with an aerodynamic diameter smaller than or equal to a nominal $10 \mu \mathrm{m})$ standard in the range of 50 to $60 \mu \mathrm{g} / \mathrm{m}^{3}$ based on Its staff assessment of long-term epidemlologic studies which support "no significant effects" in the concentration range of 80 to $110 \mu \mathrm{g} / \mathrm{m}^{3}$ TSP or in equivalent $\mathrm{PM}_{10}$ leve1s, 40 to $55 \mu \mathrm{g} / \mathrm{m}^{3}$.

Host of the up-to-date Information on afrborne particle toxicity and epidemiologic information regarding the population-based exposure-response relationships used in the risk and analytic approach in this study are contalned in the recent Harvard Health and Environmental Effects Docunerit (HEEDs) on alrborne particles.15,16,17 The afrborne particle HEEDs are the product of a multi-disciplinary DOE study and are intended to summarize results to-date of continuing analyses of the nature, magnitude and uncertainty of potential health Impacts of alrborne particles. One of the main objectives of Harvard's assessments, reported in these HEEDS, is the 1dentification of: limitations, gaps in knowledge, and research needs in the area of health risks resulting from population exposures to ambient particles. Also used were results from a recent EPA study on benefit analys is of alternative amblent standards for particulates. 18 


\subsection{Morbidity Ef fects Anal ysis}

In an attempt to quantify the morbidity effects of $1154 \mathrm{MT} / \mathrm{gr}$ coal particle emissions, several well regarded studies that provided quantitative estimates for alr pollution concentration and morbidity outcomes were selected. A study of hospital visits conducted by samet and his co-vorkers 19 addresses a concentration range for particles that is relevant to air pollution levels in the study area. The other studies (Ferris et al.20,21 and Saric et al. ${ }^{22}$ ) address relatively high particulate levels, and one must extrapolate using linear exposure-response models beyond the range of observed concentrations in these studies in order to derive a risk coefficlent. How ever, this approach must be taken cautlously as very little evidence exists to Indicate whether or not the relationships observed at higher particle concentrations hold at lower concentrations. Although the EPA has excluded this study from its criteria document, other researchers have included it to allow the projection of conservative estimates. 16,18

With these qualffications, the coefficients used for predicting acute morbidity included a coefficient for excess emergency room vistts for respiratory disease, derived from the Samet et al. study, ${ }^{19}$ with a value of 13 \pm 6.5 cases/year $/ 100,000$ persons per $\mu g / \mathrm{m}^{3} \mathrm{TSP}$. The conservative ( $1 . \mathrm{e}_{0}$, near upper-bound) age-specific coefficients used to project acute respiratory disease incldents obtained from the saric et al. stud $y^{22}$ were:

Age Rlsk Coefficient

$$
\begin{aligned}
& 0-24 \text { years } \\
& 25-54 \text { years } \\
& 55+\text { years }
\end{aligned}
$$

* Acute respiratory disease incidents/year/100,000 per $\mathrm{pg} / \mathrm{m}^{3} \mathrm{TSP}$. 
Due to uncertainties in the application of the Saric results to this study, zero was used as the lower-bound limit and 1.5 times the estimated coefficlent was used to compute the upper 957 confidence 1 imlt.

In addition to the extrapolation problem, the range of coefficients presented above logically include zero because there are other Important contributors to the uncertainties of the morbidity risk estimates. These can be categorlzed into sampling and non-sampling errors associated with the epidemiologic studies of both the morbidity and the mortality effects of alr pollution. Sampling errors refer to the lack of precision of a sample result. If a sample were to be collected without sampling error, then one could rapriduce from the sample the results which would have been obtained if the entire population had been included. To the extent that this is not true, sampling error exists. Non-sampling errors include a varlety of factors that influence the uncertainty of the estimated airborne particle concentra:ionresponse relationships. They include: confounding factors (e.g., cigarette smoking, soclo-economic status, occupational exposures, race, prior exposures and residence); collinearities with other pollutants (e.g., particles and sulf, : dioxide); changing measures of particle pollution that are not entirely comparable [e.g., British Smoke (BS)* or Coefficlent of Haze (COH)** versus TSP]; oversimplifications in estimating personal exposures from data collected at flxed-site monitors; and blases due to historical and cross-community

\footnotetext{
* British Smoke. An optical aerosol measurement used more commonly in Europe and expressed in $\mathrm{ug} / \mathrm{m}^{3}$. It is obtained by measurement of the decreased reflectance of a filier paper after the passage of a measured volume of a1r.

** Coefficient of Haze. An optical aerosol measurement used to quantify the mass of particle deposit on a filter tape sampler by measuring the percent transmission of white liglt through it.
} 
differences in particle and source composition.

Due to potential contributions by the factors noted, the standard errors cf the estimates have typically been defined half as large as the estimates themselves. 15 Using these standard errors, the $95 \%$ confidence 1imits are estimated by adding (or subtracting) twice the standard error to the mean rlsk estimate. Negative lower-bound estimates, If obtained, are set at zero, since beneficial effects of alr pollution are not readily plausible.

Table 2 summarlzes the most likely acute morbidity effects assoclated with afrborne particles emitted from the Kyger Creek power plants. Table 3

(Tables 2 and 3 about here)

provides the corresponding uncertainty limits for these projected health effects. For the area surrounding the kyger Creek facility, the incremental excess emergency roor visits for respiratory disease would be about one case every two years ( 0.5 por year). Whereas, the expected number of incremental annual acute respiratory disease incldents for the same areas are about 11 per year.

Estimates for chronic morbldity effects were not included since the avallable coefficients are derived from the studies of Ferris and his colleagues $^{20,21}$ based on amblent levels typlcally greater than $130 \mu \mathrm{g} / \mathrm{m}^{3}$, and thus significantly larger than the baselfne plus incrementai in this analysis.

\subsection{Results of Mortality Effects Anal ys is}

In order to quantif $y$ the acute and the chronic exposure moxtality effects of afrborne particles, mortality coefficients derived from time-series and cross-sectional analysis reported in the Harvard 15,16 and the Matht zch 18 reports were chosen. In addition, an upgraded cross-sectional mortality 
analysis was performed using the 1980 census and vital statistics data in conjunstion with FP (fine particles, 1.e., aerodynamic diameter smaller than $2.5 \mathrm{pm}$ ) data for the same period.

Only the effects of particle poilution on total mortality 1.e., changes In the mortgitty from all causes, were analyzed. From time-serles analyses providing dally mortality risk coefficients, the following coefficlents derived from the analysis of 14 years of dally New York City mortality and air pollution records were considered:

$0.02 \pm 0.005$ deaths/day/100,000 persons per unit $\mathrm{COH}^{15}$

$0.046 \pm 0.007$ deaths $/$ day/100,000 persons per untt $\mathrm{COH}^{17}$

Both of thes time-series coefficients were used to present a range. Before application, the coefficients were converted to representative TSP levels by scaling with a factor of 0.01 . (This was based upon site-specific analysis using 500 same-day measurements, conducted at the C1ty College of New York, of $\mathrm{COH}$ and TSP.) The coefficient was further adjusted to account for the difference in the size distribution of the projected power plant particle emissions. The converston used was a scaling upward by a factor of $1 / 0.54$; since IP (1.e., smaller than $15 \mu \mathrm{m}$ ) mass 1s, on the average, $54 \%$ of the TSP mass. 23

From cross-sectional murtality analysis, the following sets of coefficients were considered:

$0-0.47$ deaths $/$ year $/ \mu g / \mathrm{m}^{3}$ TSP per 100,000 persons 18

$0.4 \pm 0.24$ deaths $/$ year $/ \mu g / \mathrm{m}^{3}$ isP per 100,000 persons $^{16}$

$2.31 \pm 0.81$ deaths $/$ year $/ \mu g / \mathrm{m}^{3}$ FP per 100,000 persons 17

The final range of cross-sectional mortality coefficlents selected were 0 to $2.31 \pm 0.81$ deaths/year $/ 100,000$ persons per $\mu \mathrm{g} / \mathrm{m}^{3} \mathrm{FP}$ (since all the other coefficients, tf used, would project mortality impacts within the range generated by these risk coefficients). 
Although the latest fine particle coefficient ${ }^{17}$ should provide an Improvemenc over the previously reported cross-sectional mortality coefficient $z$ of particle pollution, there are still large uncertainties surrounding any such damage coefficient. Indeed, despite the fact that the coefficisnt is statistically greater than zero, uncertainties which are not considered by such analyses le.g., non-sampling errors such as in the measurement of the exposure varlable] make it possible that the particle mirtality risk coefficient might be zero.

Tables 2 and 3 sumarize the predicted mortality impacts and their associated uncertalnties, respectively. The most likely annual mortality risks associated with emissions from the Kyger Creek plant are less than 0.03 per year within the 50-mile radius of the plant. Predicted average dally mortality risks from the Kyger Creek plant would likely be $0.8 \times 10^{-5}$ to $1.9 \times$ $10^{-5}$ deaths per day associated with the 1154 (MT/yr) particle emissions. These daily projections, if multiplied by 365 , are st111 less than one-third of the annual mortality projections based upon using risk coefficients derlved from cross-sectional mortality studies.

Based upon analysis of the dally population exposure projections within the 50-mile radius surrounding the Kyger Creek plant, the maximum 24-hour IP exposure is 49,000 person-ug/m $/ \mathrm{m}^{3}$ to give a maximum dally mortality of $4.2 \times 10^{-4}$ excess deaths.

\subsection{Estlmated Incremental Health Risk Compared to Baseline Values}

Sclentificalig, the significance of the health risk projections can usually be demonstrated by comparison with the baseline morbidity and mortality rates in the areas studled. However, even in terms of absolute effects, both the concentration and the mottallty effects are significantly 
below the detectable or observable levels in the region studied. Profected morbidity effects are also very small and well below the sampling error in most epidemlologic surveys.

To compare the profected mortality and the morbidity risks to expected baselize values, the socio-demographic profile of the population near these three plants was thoroughly examined. It was determined that: (a) the population characteristics are typical $r f$ the national average; and (b) national disease incidence rates and the cross-sectional mortality model developed using a national data base can be applied reliably in projecting the baseline risks in the region studied.

The 1980 cross-sectional model was first used to predict the areaspecific total mortality rates (TMR) using the socio-demographic information obtained from the 1980 census for the areas surrounding the three plants. Tnese predictions were then checked for consistency with the observed mortality rates in 14 cities in Indiana and ohio. It was foun that the results were in excellent agreement. 5

The model that was used to predict the annual TMR was obtalned from a multiple-regression analysis of the 1980 U.S. census and air pollution data. The regression coefficients of the model chosen accounted separately for the contribution of the following independent variables to the predicted TMR: percentage of the population over 65 years olj; median age of population; percentage of population which is non-white; decimal logarithm of the population density; percentage of population with more than 1 year of college; percentage of families with an annual income less than $\$ 5,000$; and estimated fine particle mass. The predicted total mortality rates are noted to vary between 814 and 1,084 deaths per 100,000 persons per year and are consistent with the observed Midwest average, $895 \pm 108$. 
A rate for the dally hospital emergency room visite from all causes was derived from the Samet, et al., study $y^{19}$ to be $24.5 / 20,000$, or $1.22 \times 10^{-2}$ visits per day per person. For annual acute respiratory disease incidence rates, the age-specif1c rates used were: ${ }^{18} 1.52(0-24$ years), $1(25-55$ years), and 0.7 ( $55 \%$ years) annual acute respiratory disease incidents per person in the U.3.

Expected excess emergency room visits due to respiratory conditions were 389,000. The expected annual acute resplratory incidents are 979,000 for this area. Total annual mortality are estimated to be 7,500 deaths in the Kyger Creek area. These absolute values in the Kyger Creek area are quite large due to the size of the population and the magnitude of the expected incidence or prevalence rates.

The percentage of change in the expected incidence of total vorbidity resulting from the Incremental $1154 \mathrm{MT} / \mathrm{yr}$ particle emission in the Kyger Creek area is very small ( 0.0001 to 0.005 percent). The likely percentage of change in the expected annual total mortality resulting from the incremental particle emissions is less than 0.0004 percent. Both in terms of absolute numbers and In terms of relative proportions compared to baseline health impacts in the areas analyzed, the projected lmpacts are very small. Furtherwore, concentration as well as health impacts are 80 small that they could not even be detected with the state-of-the-art monitoring, survey design, and analysis techniques. Finally, all of the projected health 1mpacts are much smaller than the uncertaintles assoclated with the avallable risk assessment models

* These rates are somewhat higher than the national average aince the hospital used in this study was in Steubenville, ohio, which is in an industrial valley town with iron and steel plants, coal-fired power plants, and chemical plants. 
añd the predictions resulting from their use.

4. DISCUSSION AND CONCLUSIONS

The following additional general conclusions can be made regarding the coal particulates health risk analysis presented in this paper, and in particular the use of similar analysis in formal regulatory proceedings:

1. Risk management through the formal regulatory hearing, or simflar legal process, is the rechanism by whlch sclentiflc risk assessment has a direct impact on socletal decisions. Sclentists involved $1 \mathrm{n}$ risk assessment should thus have an awareness of the demands and constraints of the process.

2. The regulatory process can force resolution of scientific 1ssues. A foremost example 1s the extent to which the IInear dose-response model should be ut $111 z e d$. Exposures of large populations to low concentrations of hazardous pollutants can lead to exaggerated estimates of health effects with the linear model if caution is not used. Also, during crossexamination in this hearing the need for dose-response data based specifically on coal particulates was emphasized, although the uncertainty limits used for the coefficients in the analysis were intended to take into acvount variability in particulate characteristics.

3. Legally defined constraints of the regulatory process may limit development of more comprehensive perspectives. For example, in the risk assessment presented in this paper, the analysts were constrained to consider only previously defined obsolete emission estlmates; effects of other poilutants, such as secondary particulates from sulfur emissions, were not considered; and the health effect benefits/costs from coal plants being displaced by the nuclear plant were excluded from consideration at this hearing. 
4. Uncertainty analysis is a necessary component of risk assessments that are to be used in the risk management (regulatory) process, however, there is a natural tendency to misuse extreme values in the ranges to support particular views. Central or most-likely estimates should thus be derived when possible and clear explanations of the basis for the uncertainty limits should be provided.

At the date of the writing of this paper no decision on the significance of the health effects of the coal particulates in the uranlum fuel cycle has been made by the ASLB.

ACKNOWLEDGEMENT

The support for this study by the Unfted States Nuclear Regulatory Commission is gratefully acknowledged.

REFERENCES

1. Code of Federal Regulations, Title 10, Part 561, Licensing and Regulatory Pollcy and Procedures for Environmental Protection.

2. "Environmental Survey of the Uranium Fuel Cycle," WASH-1248, Directorate of Licensing, Atomic Energy Commisston, Washington, D.C. (1974).

3. "Draft Environmental Statement, Shearon Harris Nuclear Power Plant, Units 1 and 2," NUREG-0972, U.S. Nuclear Regulatory Comm1ssion (1983)

4. Atomic Safety and Licensing Board Order of January 27, 1984, In the Operating License Proceedings for Harris Units 1 and 2. 
5. NRC Staff Testimony of Dr. Loren .J. Habegger, Dr. A. Hâluk ${ }_{\text {zka ynak, and }}$ Mr. Ronald L. Ballard Regarding Eddleman Contention BF(1) (Health Effects of Coal Particulates at the Table S-3 Level), before Atomic Safety and Licensing Board in the Operating License Proceedings for the Harr1s Units 1 and 2 (June 15, 1984).

6. U.S. Federal Power Commission, Form 67, "Steam-Electric Plant Alr and Hater Quality Control Data," Kyger Creek Electric Station (1980).

7. "Assessment of Energy and Economic Impacts of Particulate-Contro1 Technologies in Coal-Fired Power Generation,"ANL/ECT-9, Midwest Research Institute and Argonne National Laboracory, Argonne, IL (1980).

8. "Industrial Source Complex (ISC) Dispersion Model User's Guide," EPA450/4-79-030, U.S. Environmental Protection Agency, Research Triangle Park, NC (1979).

9. Heron, T.M., J.F. Kelly, P.G. Haateja, "Validation of the Industrial Source Complex Dispersion Model in a Rural Setting," Jouro of the Air Pol1. Control Assoc., Vo1. 31, No. 4 (April 1984).

10. Londergan, R., D. Minott, D. Wackter, T. Kincaid, and D. Bonitata, "Evaluation of Rural A1r Quality Simulation Models," EPA-450/4-83-003, U.S. Environmental Protection Agency, Research Triangle Park, NC (1982).

11. "1977 Clean AIr Act Amendments to Prevent Significant Deterioration," 43 FR 26380 (June 19, 1978). 
12. "The Revised Criteria Document: Atr Quality Criteria for Porticulate Matter and Sulfur Oxides" (three volumes), U.S. Environmental Protection Agency, EPA $600 / 8-82-029 a-c$ (December 1982).

13. "Review of the National Alr Quality Standards for Particulate Matter: Assessment of Scientific and Technical Information", OAQPS staff paper, U.S. Environmental Protection Agency, Er.4-450/5-82-001 (January 1982).

14. Federal Register, "Proposed Revisions to the National Ambient Air Qual1ty Standards for Particulate Matter", V49, N55 (March 20, 1984 ).

15. "Ozkaynak, H., G.D. Thurston, T.D. Tosteson, C.M. Smith, P.L. Kinney, B. Beck, W. Skornik, S.D. Colume and A. Schatz, "Analysis of Health Effects Resulting from Population Exposures to Ambient Particulate Matter," prepared by harvard University for the U.S. Department of Energy, Contract No. DE-AC02-81EV10731 (October 1983).

16. Özkaynak, H., J.A. Warren, T.D. Tosteson, J.S. Evans, G.D. Thurston and S.D. Colome, "Analysis of Health Effects Resulting from Population Exposures to Ambient Particulate Matter," prepared by Harvard University for the U.S. Department of Energy, Contract No. DE-AC02-81EV10731 (October 1982).

17. Özkaynak, H., "Analysis of Health Effects Resulting from Population Exposures to Ambient Particulate Matter," Harvard University, 1984 Revisions (in preparation). 
18. Manue1, E.H., R.H. Horst, Jr., R.M. Brennan, J.M. Hobart, C.D. Harvey, J.T. Bentley, M.C. Duff, D.E. Klinger and J.K. Taplero, "Benefit and New Benefit Analysis of Alternative National Anblent Alr Quality Standards for Particulate Matter," prepared by Mathtech, Inc. For Benefits Analysis Program, Economic Analysis Branch, Office of Air Quality Planning and Standards, U.S. Environmental Protection Agency, Contract No. 68-02-3826 (March 1983).

19. Samet, J.M., F.E. Speizer, Y. Bishop, I... Spengler and B.G. Ferris, Jr., "The Relationshins piseen Air Pollution and Emergency Room Visits In an Industrial Communtey," J. Alr Pollut. Control; Assoc., 31:236-240 (1981).

20. Ferris, B.G., Jr., H. Chen, S. Puleo and R.L.H. Murphy, Jr., "Chrontc Non-Speciflc Respiratory Disease in Berlin, New Hampshire, 1967-1973: A Further Follow-up Study," Amer. Rev. Resp. D1s., 113:475-485 (1976).

21. Ferris, B.G., Jr., I. Higgins, M.W. Higgins and J.M. Peters, "Chronic Non-Specific Respiratory Disease In Ber1in, New Hampshire, 1961-1967: A Follow-up Study," Amer. Rev. Resp. D1s., 107:110-122 (1973).

22. Saric, M., M. Fugas and 0. Hurstic, "Effects of Urban Air Pollution on School-Age Ch1ldren," Arct. Environ. Health, 36:101-108 (1981).

23. Ozkaynak, H., G.D. Thurston, A.D. Schatr, R.G. Isaacs and R.B. Husar, "Relationships between Aerosol Extinction Coefficients Derived from Airport Visual Range Observations and Alternative Measures of A1rborne Particle Mass, paper no. 84-59.2, 77th Annual Meeting of the Air Pollution Control Assoclation, San Francisco, CA (June 24-29, 1984 ). 
Table 1

Comparison of Area-Specific Baseline Particle Pollution Concentrations and Population Exposures to Impacts Associated with the

Kyger Creek Power Plant*

\section{Baseline Values*t}

Annual Average $\left(\mathrm{ug} / \mathrm{m}^{3}\right)$

TSP FP

68
Population Exposures

$\left(\mathrm{ug} / \mathrm{m}^{3} \times\right.$ persons $)$

TSP

$5.9 \times 10^{7}$
$2.1 \times 10^{7}$

\section{Projected Increments}

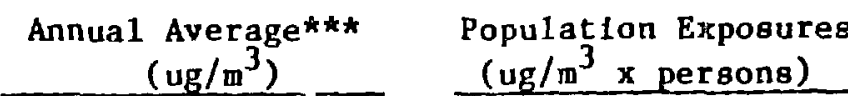

$\begin{array}{llll}0.003- & 0.002- & 1,990- & 1,353- \\ 0.004 & 0.003 & 2,436 & 1,656 \\ \text { (mean }= & \text { (mean } & \text { (mean }= & \text { (mean } \\ 0.0033) & 0.002) & 2,174) & 1,478 \text { ) }\end{array}$

* 50-mile radius around the power plant defines the study area. Projected range of 1mpacts 18 based upon $j$ years of meteorology (1971-1975).

IP refers to the mass of Inhalable Particles (aerod ynamic diameter < 15 um) and typical1y, IP $1854 \%$ of TSP in the ambient atmosphere. ${ }^{23}$ FP refers to the mass of Fine Particles (aerod ynamle dlameter $<2.5$ um.)

* Mean TSP concentrations are based on: 1) NASN data for countles surrounding and Including the power plants (data for years 1978-1981), 2) EPA Inhalable Particle Network data for (urban) gites near the power plants (data for years 1978-1982), and 3) EPRI/SURE measurements at nearby (rural) class loites (data for 1977-1979).

* A* Annual averageg are calculated by averaging over all grid cells. 
Table 2

Summary of Most Likely Profected Population Health Effects

Associated with Alrborne Particles Emitted from the

Kyger Creek Power Plant Supplying Electricity

to the Uranium Fuel Cycle*

Acute Morbidity Effects

Annual No, of

Emergency Room

visits for

Respiratory

Disease
Annual Acute

Respiratory

Disease

Incidents*

$0.5 \quad 11 \quad 0.8 \times 10^{-5}-1.9 \times 10^{-5} \quad 0-0.03$

* Uncertaintles due to sampling and non-sampling errors are not included here. Therefore, zero risks are also possible.

** These are tentative results and should be considered to be conservative due to inherent problems associated with the interpretation of the Saric et al. study 22 which was used in developirig the health risk coefficlents. 
Table 3

Uncertainty Lfolts ( $95 \%$ Confidence) for the Projected

Health Effecto (Kyger Creek)

Acute Morbidity Effects

Annual No. of
Emergency Room
Vists for
Respiratory
Disease

$0-1.0$

$0-17$
Mortality Effects

Annual

Acute

Respiratory

Disease

Incidents

Mortality $y^{\text {h }}$ Mortality

$0.4 \times 10^{-5}$

$-2.5 \times 10^{-5}$

* Uncertainties due to non-sampling errors not included, 1.e., the possibilicy of zero as a lower limit is not excluded. 